\title{
ŚCIEŻKI RÓWNOWAGI STATYCZNEJ BELEK ŻELBETOWYCH WZMACNIANYCH TAŚMAMI Z WLÓKIEN WĘGLOWYCH
}

\begin{abstract}
Wyniki badań doświadczalnych i analiz numerycznych pokazują, że istotny wpływ na pracę wzmacnianych belek żelbetowych mają techniki naprawcze i właściwości mechaniczne zastosowanych materiałów naprawczych. Właściwości mechaniczne materiałów naprawczych oraz techniki wzmacniania decydują nie tylko o nośności belek po wzmocnieniu, ale także o ich odkształceniach. Ponadto wzmocnienia belek mogą być wykonywane przy zastosowaniu różnych metod. Wzmocnienie można wykonać przed obciążeniem belki lub po jej obciążeniu. Można też belkę odciążyć przed wzmocnieniem, albo sprężyć ją materiałami naprawczymi. Wymienione metody naprawcze mają również wpływ na pracę wzmacnianych belek żelbetowych. Projektując wzmocnienia belek żelbetowych trzeba być świadomym konsekwencji stosowania dostępnych technik naprawczych, materiałów naprawczych, a także wyboru metody wykonywania wzmocnien. W artykule przedstawiono ścieżki równowagi statycznej belek żelbetowych wzmacnianych różnymi materiałami naprawczymi przy zastosowaniu różnych technik wzmacniania i metod wzmacniania, ze szczególnym uwzględnieniem wzmocnień taśmami z włókien węglowych. Przeprowadzone analizy mogą być pomocne w projektowaniu wzmocnień belek żelbetowych.
\end{abstract}

Słowa kluczowe: obciążenie, odciążenie, sprężenie, moment zginający, krzywizna, ugięcie.

\section{Wprowadzenie}

Wzmocnienia konstrukcji wykonywane są często podczas remontów, modernizacji czy też renowacji obiektów budowlanych. Ich celem jest przywrócenie konstrukcji pierwotnej nośności lub zwiększenie jej nośności ze względu na nowe większe projektowane obciążenia. Do wzmocnienia konstrukcji betonowych stosowane są bardzo różne technologie i materiały naprawcze [12]. O skuteczności wzmocnienia decyduje tzw. ,inżynieria napraw” [2], natomiast wpływ na efektywność wzmocnienia tj. uzyskanie zwiększonej nośności i odpowiedniej

\footnotetext{
${ }^{1}$ Jacek Korentz, Uniwersytet Zielonogórski, 65-417 Zielona Góra, ul. Licealna 9, tel. +48 6832882 416, e-mail: j.korentz@ib.uz.zgora.pl
} 
odkształcalności, mają cechy mechaniczne zastosowanych materiałów naprawczych, a także zastosowane techniki $[4,5,11]$ i metody wzmacniania.

Do wzmocnień konstrukcji żelbetowych najczęściej stosowane są taśmy z włókien węglowych CFRP. Stosowane są też pręty i kształtowniki stalowe, a także sploty. Możliwe jest też stosowanie taśm i mat $\mathrm{z}$ włókien szklanych GFRP i aramidowych AFRP. Są to materiały o bardzo różnych właściwościach mechanicznych. Pośród technik wzmacniania stosowanych podczas wzmacniania elementów zginanych można między innymi wymienić: zwiększanie wymiarów przekroju betonowego, zastosowanie dodatkowego zbrojenia rozciąganego, spajanie z kształtownikami stalowymi, doklejanie taśm FRP, wklejanie taśm FRP, zmiana schematu statycznego, a także wzmacnianie zbrojeniem aktywnym poprzez sprężenie $[13,15]$. Jeżeli chodzi o metody wzmacniania belek żelbetowych to można wyróżnić następujące metody: wzmacnianie przed obciążeniem, wzmacnianie pod obciążeniem, wzmacnianie po odciążeniu, a także sprężanie.

Najwięcej dostępnych badań doświadczalnych poświęconych jest wzmocnieniom wykonywanym przed obciążeniem, badań doświadczalnych elementów wzmacnianych pod obciążeniem, elementów wzmacnianych po odciążeniu, czy też po jego sprężeniu materiałem naprawczym jest znacznie mniej. W praktyce mamy do czynienia z przypadkiem, gdy wzmacniamy istniejące elementy konstrukcyjne, które są już obciążone, a do tego występują już w nich deformacje trwałe. Różnica w pracy elementów konstrukcyjnych wzmacnianych przy zastosowaniu różnych materiałów naprawczych i wymienionych metod wzmocnienia jest istotna i powinna być uwzględniana w projektowaniu wzmocnień belek żelbetowych w strefie zginania.

Znajomość ścieżek równowagi statycznej dla różnych metod wzmocnienia może pozwolić na ich racjonalny wybór tak ażeby osiągnąć zamierzony cel dotyczący pracy wzmacnianego elementu dla projektowanego przeznaczenia obiektu. W artykule zaprezentowano ścieżki równowagi statycznej dla różnych materiałów naprawczych i różnych metod wzmacniania belek żelbetowych w strefie maksymalnego momentu zginającego.

\section{Fazy pracy zginanej belki żelbetowej bez i ze wzmocnieniem}

$\mathrm{W}$ niniejszej analizie, $\mathrm{w}$ zakresie obciążeń doraźnych $(\mathrm{t}=0)$, porównano pracę belki żelbetowej z pracą takiej samej belki wzmocnionej przed obciążeniem kompozytem węglowym CFRP. Rysunek 1. przedstawia uproszczone zależności pomiędzy momentem zginającym $M$ a krzywizną $\varphi$ w przekroju. Linia $\mathrm{OC}_{\mathrm{c}} \mathrm{Y}_{\mathrm{c}} \mathrm{U}_{\mathrm{c}}$ i linia $\mathrm{OC}_{\mathrm{CL}} \mathrm{Y}_{\mathrm{CL}} \mathrm{U}_{\mathrm{CL}} \mathrm{U}$ ilustrują zachowanie się odpowiednio przekroju żelbetowego bez i ze wzmocnieniem. Dodatkowo zamieszczono linię $\mathrm{OC}_{\mathrm{L}} \mathrm{U}_{\mathrm{L}}$ przedstawiającą zachowanie się przekroju betonowego zbrojonego tylko kompozytem. Na rysunku tym punkty $\mathrm{C}$ na wykresach oznaczają zarysowanie przekroju, punkty Y uplastycznienie rozciąganego zbrojenia belki, natomiast punkty $\mathrm{U}$ oznaczają wyczerpanie nośności przekroju. 
W przypadku przekroju żelbetowego znane fazy jego pracy to: praca przekroju niezarysowanego - linia $\mathrm{OC}_{c}$, praca przekroju zarysowanego $\mathrm{C}_{\mathrm{c}} \mathrm{Y}_{\mathrm{c}}$ i praca przekroju uplastycznionego $\mathrm{Y}_{\mathrm{c}} \mathrm{U}_{\mathrm{c}}$ do chwili wyczerpania jego nośności, którym może być umowne odkształcenie graniczne w betonie lub zbrojeniu, albo zerwanie zbrojenia rozciąganego lub niesprężyste wyboczenie ściskanych prętów zbrojenia podłużnego [7]. W pracy przekroju wzmocnionego można wyróżnić takie same pierwsze trzy fazy pracy jak dla przekroju żelbetowym bez wzmocnienia [6]: praca przekroju niezarysowanego $\mathrm{OC}_{\mathrm{CL}}$, zarysowanego $\mathrm{C}_{\mathrm{CL}} \mathrm{Y}_{\mathrm{CL}}$ i uplastycznionego $Y_{C L} U_{C L}$. Przyczyny wyczerpania nośności wzmocnionej żelbetowej belki w strefie zginania mogą być bardzo różne [14]. Jeżeli wzmocnienie belki doklejanymi taśmami CFRP jest prawidłowo zaprojektowane i wykonane to wyczerpanie jej nośności (punkt $\mathrm{U}_{\mathrm{CL}}$ ) ma miejsce w chwili delaminacji kompozytu, tj. po przekroczeniu odkształceń, które są znacznie mniejsze od odkształceń granicznych w kompozycie [11]. Dlatego wykorzystanie pełnej nośności kompozytu przy tej technice wzmocnienia nie jest możliwe. Odspojenie kompozytu zaczyna się w sąsiedztwie końca taśmy albo w obszarze maksymalnego momentu zginającego i następnie postępuje bardzo szybko na jej długości ku środkowi taśmy lub do jej końca [4]. Jeżeli taśmy z włókna węglowego są wklejane w otulinę belki to można wykorzystać w pełni ich wytrzymałość; do wyczerpania nośności przekroju w tym przypadku dochodzi w wyniku zerwania taśm [10].

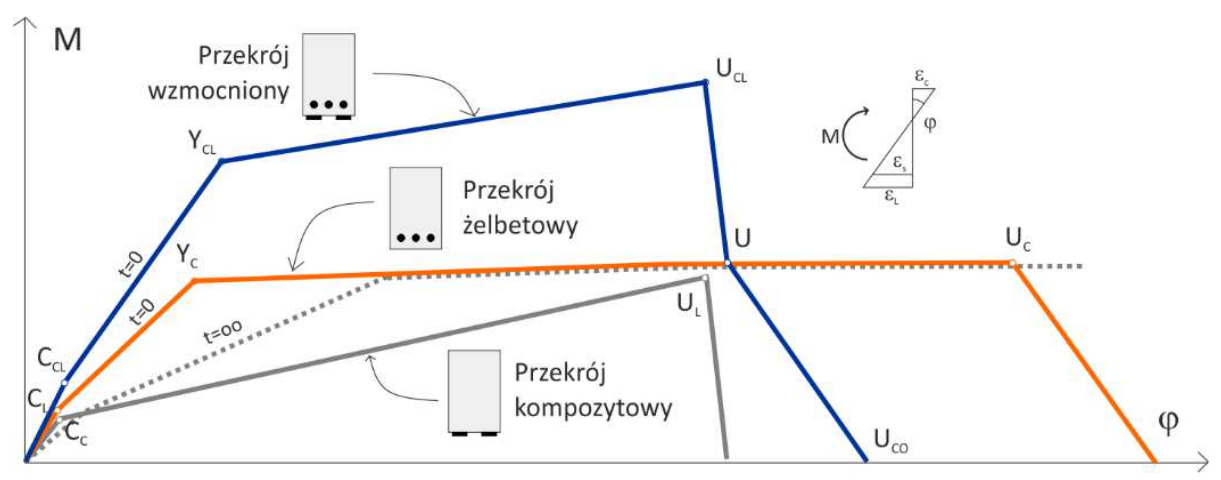

Rys. 1. Fazy pracy przekroju żelbetowego, wzmocnionego i kompozytowego

Fig. 1. The phases of work of RC section, RC strengthened section and CRFP-C section

W chwili delaminacji materiału naprawczego, w tym przypadku kompozytu węglowego, wzmocniona belka na chwilę przechodzi w fazę pracy belki żelbetowej (punkt U), o jej nośności decyduje nośność przekroju żelbetowego, a zachowanie się przekroju ,wzmocnionego" w tej fazie wytężenia ilustruje linia $\mathrm{UU}_{\mathrm{Co}}$. Obciążenie graniczne oddziaływujące po wzmocnieniu powoduje raptowne wyczerpanie nośności krytycznego przekroju wzmocnionego a następnie przekroju żelbetowego. W badaniach doświadczalnych, w których podczas ba- 
dań ma miejsce sterowanie przemieszczeniem ścieżka równowagi statycznej po delaminacji przebiega po linii $\mathrm{U}_{\mathrm{CL}} \mathrm{UU}_{\mathrm{C}}$.

Dodatkowo na rys.1 linią przerywaną zilustrowano zachowanie się przekroju żelbetowego z uwzględnieniem wpływu pełzania $(\mathrm{t}=\infty)$.

\section{3. Ścieżki równowagi statycznej}

Opisem zachowania się elementów konstrukcyjnych i konstrukcji pod wpływem działających obciążeń we wszystkich fazach ich pracy są ścieżki równowagi statycznej, na których można obserwować między innymi zależności między momentem zginającym a krzywizną. Są one bardzo przydatne w analizach porównawczych zachowania się różnych elementów konstrukcyjnych pod obciążeniem, a także w budowaniu modeli fizycznych [1].

\subsection{Wpływ właściwości mechanicznych materiałów naprawczych}

Jak już wcześniej wspomniano duży wpływ na zachowanie się wzmacnianych elementów mają właściwości mechaniczne materiałów naprawczych. Rys. 2 ilustruje wpływ właściwości mechanicznych materiałów naprawczych na zachowanie się wzmocnionego pod obciążeniem przekroju żelbetowego [5].

Są to wyniki analiz numerycznych wykonanych programem XTRACT [16]. Rozpatrywane są trzy techniki wzmocnienia przekroju żelbetowego B-0 (rys. 2a): wzmocnienie dodatkowym zbrojeniem prętami i betonem natryskowym (przekrój B-Z), wzmocnienie taśmami CFRP wysoko modułowymi (przekrój BF1) i nisko modułowymi (przekrój B-F2), wzmocnienie płaskownikami stalowymi (przekrój B-S). Na rys. 2a zamieszczono również dane geometryczne przekrojów i zależności $\sigma-\varepsilon$ określające właściwości mechaniczne zastosowanych materiałów. Na rys. 2 b krzywa B-0 przedstawia zależność moment krzywizna dla przekroju żelbetowego, a pozostałe krzywe ilustrują zachowanie się przekrojów wzmocnionych wymienionymi wyżej technikami i materiałami.

Nośność przekroju przed wzmocnieniem wynosiła $\mathrm{M}_{\mathrm{u}}=265 \mathrm{kNm}$. Zakłada się, że zwiększenie obciążeń wymaga zwiększenia nośności o około $40 \%$ to jest do $\mathrm{M}=370 \mathrm{kNm}$. Ponadto zakłada się, że obciążenie w chwili wzmocnienia stanowi $50 \%$ dotychczasowych obciążeń całkowitych, zatem moment zginający w chwili wzmocnienia można oszacować na $\mathrm{M}_{0}=132 \mathrm{kNm}$. Obliczenia przeprowadzono dla obciążeń doraźnych, bez uwzględnienia pełzania.

Przedstawione na rys. $2 b$ ścieżki równowagi statycznej pozwalają na stwierdzenie, że uzyskanie wymaganej nośności przekroju po wzmocnieniu przy zastosowaniu określonych materiałów naprawczych nie powinno być jedynym kryterium ich wyboru. Jak można zauważyć właściwości mechaniczne materiałów naprawczych mają istotny wpływ na przebieg zmian krzywizny przekroju w zakresie obciążeń eksploatacyjnych i krzywiznę graniczną np. w chwili delaminacji kompozytu. 
a)
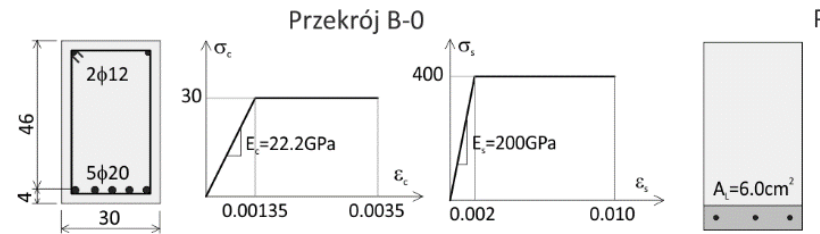

Przekrój B-Z

Przekrój B-F1

Przekrój B-F2

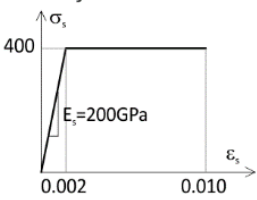

Przekrój B-S
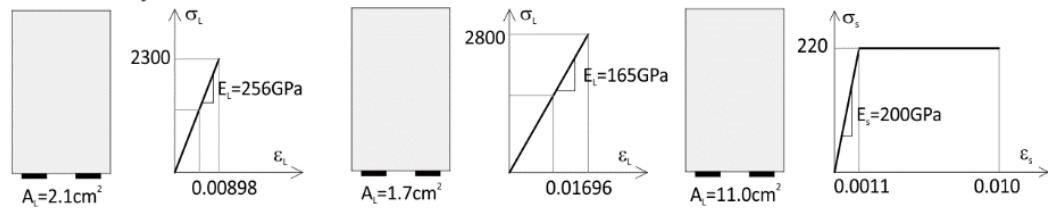

b)

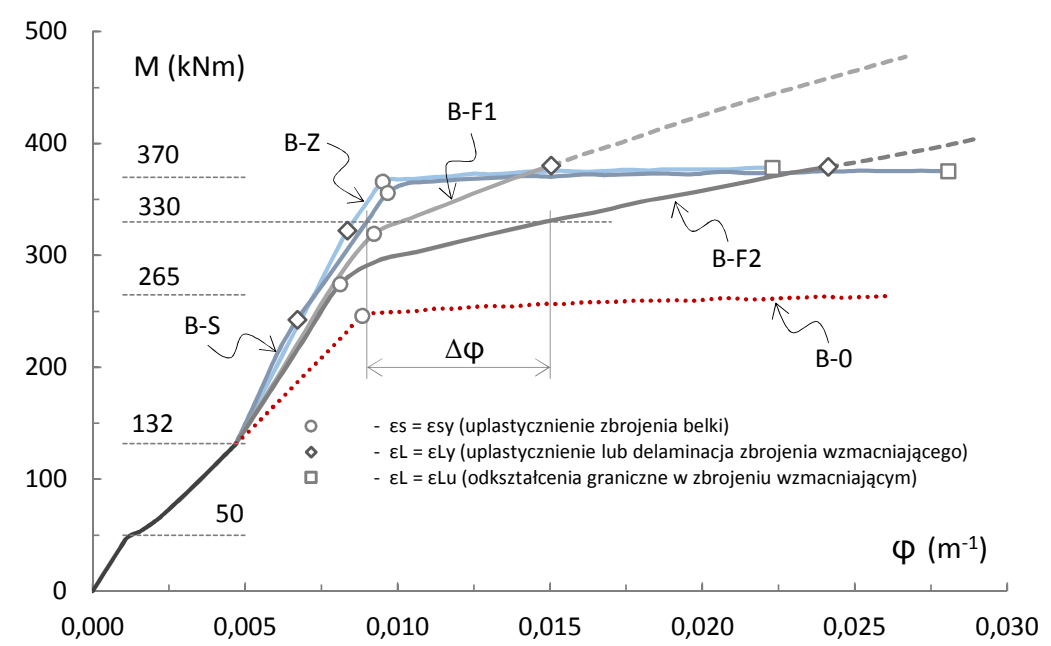

Rys. 2. Wpływ właściwości mechanicznych materiałów naprawczych na ścieżki równowagi statycznej: a) analizowane przekroje, b) zależność moment-krzywizna [5]

Fig. 2. The Effect of mechanical properties of strengthening materials on the static equilibrium path: a) analyzed cross sections, b) bending moment versus curvature [5]

Przekrój B-Z wzmocniony prętami stalowymi i przekrój B-S wzmocniony płaskownikami stalowymi zachowują się bardzo podobnie niezależnie od granicy plastyczności stali, ale odmiennie niż przekroje B-F1 i B-F2 wzmocnione taśmami z kompozytów węglowych, których zachowanie się zależy bardzo mocno od modułu sprężystości taśm. Końcowe punkty krzywych dla przekrojów wzmocnionych kompozytem (romby) oznaczają jego delaminację, co jest równoznaczne $\mathrm{z}$ wyczerpaniem nośności przekroju. $\mathrm{Z}$ tego względu dodatkowym czynnikiem decydującym o wyborze materiałów naprawczych, poza wymaganą nośnością, powinny być inne kryteria, na przykład stany graniczne użytkowalności - strzałka ugięcia, szerokość rys albo kryterium zapewnienia odpowiedniej ciągłości krzywizny przekroju lub ciągłości przemieszczeń belki. 
Na rysunku 2a linie kreskowane ilustrują zachowanie się przekrojów B-F1 i B-F2 w przypadku wzmocnienia ich techniką polegającą na wklejeniu taśm węglowych w bruzdach wykonanych w otulinie zbrojenia belki. Jak można zauważyć efektywność taśm wklejanych jest większa niż takich samych taśm doklejanych [10]. Na uwagę zasługuje również fakt, że wzmocnienie kompozytami węglowymi może spowodować, że zbrojenie belki może ulec uplastycznieniu w zakresie obciążeń eksploatacyjnych.

\subsection{Wpływ metod wzmocnienia}

Kolejnym bardzo ważnym aspektem projektowania wzmocnień belek żelbetowych są metody ich wykonywania. W rzeczywistości wzmacniane są belki $\mathrm{w}$ istniejących obiektach budowlanych, a celem wzmocnienia jest zazwyczaj zwiększenie ich nośności np. ze względu na zmianę przeznaczenia obiektu powodującą zwiększenie obciążeń użytkowych.

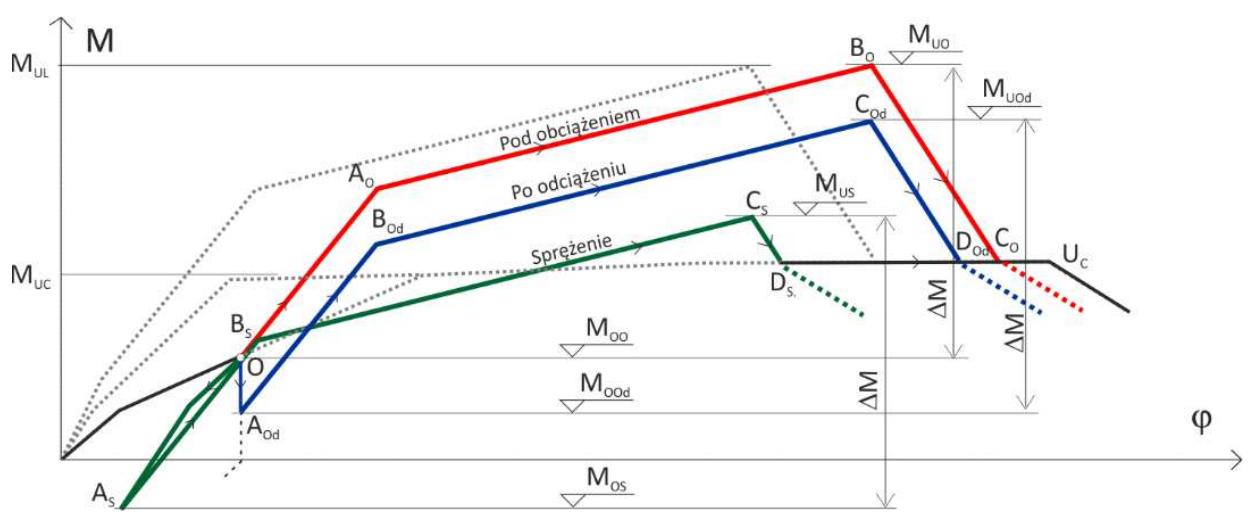

Rys. 3. Ścieżki równowagi statycznej dla różnych metod wzmocnienia.

Fig. 3. Static equilibrium paths for different strengthening methods.

Tak więc wzmocnień belek dokonuje się pod obciążeniem. Ponad to w chwili wykonywania wzmocnienia w belkach występują nieodwracalne deformacje trwałe spowodowane właściwościami reologicznym betonu. W takim przypadku możliwe są trzy metody wykonania wzmocnień: pod działającymi obciążeniami stałymi, po częściowym lub całkowitym odciążeniu wzmacnianego elementu i przez wprowadzenie siły sprężającej.

Na rysunku 3. przedstawiono trzy ścieżki równowagi statycznej, ilustrujące zależność moment zginający $M-\operatorname{krzywizna} \varphi$, dla wymienionych metod wzmocnienia wykonanych przy zastosowaniu doklejanych taśm z włókna węglowego o takim samym przekroju i właściwościach mechanicznych. Punkt „O” na rys. 3. ilustruje wytężenie przekroju w chwili przystąpienia do wykonywania wzmocnienia. Liniami kropkowanymi zaznaczono ścieżki równowagi statycznej 
przekroju żelbetowego bez i z uwzględnieniem pełzania oraz przekroju wzmocnionego przed obciążeniem (por. rys. 2.).

Linia OAOBOCO jest ścieżką równowagi statycznej dla wzmocnienia wykonanego pod obciążeniem. Nośność przekroju jest zwiększona $\mathrm{z}$ MUC do MUL=MUO, a nowoprojektowane obciążenia mogą przenieść moment zginający $\Delta \mathrm{M}$. Punkt BO oznacza wyczerpania nośności w wyniku delaminacji kompozytu. Po odklejeniu taśm przekrój przechodzi w fazę pracy przekroju żelbetowego (punkt $\mathrm{CO}$ ). Przed wykonaniem wzmocnienia można belkę odciążyć np. poprzez zdejmowanie działających obciążeń stałych, co ilustruje linia OAOd. W skrajnym przypadku belkę można odciążyć całkowicie, a także można wywołać w niej moment ujemny. Ta część ścieżki odciążenia przedstawiona jest linią przerywaną. W wyniku odciążenia zmniejszeniu ulega jedynie działający moment zginający, natomiast krzywizna przekroju tak jak i strzałka ugięcia belki pozostają bez zmian, ponieważ są one nieodwracalne. Linia OAOdBOdCOdDOd jest ścieżką równowagi statycznej dla przekroju wzmocnionego po odciążeniu. Punkt COd to chwila delaminacji kompozytu. Nośność przekroju wzmocnionego po odciążeniu MUOd jest mniejsza od nośności przekroju wzmocnionego pod obciążeniem MUO, co nie ma większego znaczenia, ponieważ po wykonaniu wzmocnienia tą metodą nowoprojektowane obciążenia również powodują przyrost momentu zginającego $\Delta \mathrm{M}$.

Kolejna metoda wzmacniania belki pod obciążeniem polega na wprowadzeniu siły sprężającej materiałami naprawczymi. Znane są technologie napinania taśm kompozytowych i ich doklejania do belki wzmacnianej [9]. Najczęściej sprężeniem odciążamy belkę a niekiedy można wywołać w belce nieduże momenty ujemne. Ścieżka równowagi statycznej przekroju wzmocnionego naprężonymi taśmami kompozytowymi ilustruje linia OASBSCSDS, a ścieżka odciążenia związana z fazą napinania kompozytu to linia OAS. Podczas wprowadzania siły sprężającej zmniejsza się moment zginający, a także krzywizna przekroju i strzałka ugięcia. W taj fazie wykonywania wzmocnienia belka pracuje sprężyście, a jej sztywność zwiększa się od chwili zamknięcia rys przy dolnej krawędzi belki. Po wykonaniu sprężenia najbardziej wytężony przekrój belki przenosi graniczny moment zginający MUS i jest on mniejszy od nośności przekroju wzmocnionego pod obciążeniem MUO i przekroju wzmocnionego po odciążeniu MUOd. Jak można zauważyć na rys. 3. przenoszony przez przekroje moment zginający $\Delta \mathrm{M}$ dla projektowanych obciążeń jest taki sam dla trzech przedstawionych metod wzmocnienia.

Jeżeli w przekroju nośność betonu strefy ściskanej jest wystarczająca i istniejące zbrojenie belki ma odpowiednią ciągliwość to wyczerpanie nośności przekroju wzmocnionego ma miejsce po przekroczeniu odkształceń w kompozycie, przy których dochodzi do jego odspojenia. W trzech analizowanych metodach wzmocnienia odkształcenia w chwili odklejenia się taśm są takie same. Dlatego w każdym z tych trzech przypadków maksymalne obciążenia $\Delta(\mathrm{g}+\mathrm{q})$ przenoszone przez przekroje po wzmocnieniu są takie same i wywołują moment zginający wynoszący $\Delta \mathrm{M}$. 


\section{Podsumowanie}

Niektóre konstrukcje wymagają wzmocnień, aby przywrócić im pierwotną nośność albo zwiększyć ich nośność ze względu na zamianę przeznaczenia obiektu. W tym celu stosowane są różne techniki wzmocnienia, w których wykorzystuje się materiały naprawcze o bardzo zróżnicowanych cechach mechanicznych. Ponad to wzmocnienia mogą być wykonywane różnymi metodami. Ostatnio bardzo często stosowane są kompozyty węglowe ze względu na ich wysoką wytrzymałość i małą odkształcalność. Kompozytami węglowymi można zwiększyć nośność elementu w znacznym stopniu, ale zwiększenie sztywności wzmocnionego elementu jest nieduże. Stąd mogą pojawić się problemy z nadmiernymi ugięciami pasywnie wzmacnianych elementów od nowoprojektowanych oddziaływań. Mankament ten można wyeliminować za pomocą czynnego zbrojenia kompozytowego stosując sprężenie. Ponad to istniejące zbrojenie we wzmacnianych belkach może ulec uplastycznieniu w zakresie obciążeń eksploatacyjnych. O ile wymiarowanie zbrojenia wzmacniającego nie stanowi większego problemu, to obliczanie ugięcia może sprawić trudność, ponieważ znane metody obliczania odkształceń wzmocnionych belek żelbetowych [3] oparte są na modelach dwufazowych, w których nie uwzględnia się uplastycznienie zbrojenia. Zaprezentowane ścieżki równowagi statycznej dla wzmacnianych przekrojów żelbetowych w postaci zależności moment - krzywizna mogą stanowić podstawę do opracowania metod obliczania odkształceń belek żelbetowych wzmacnianych różnymi materiałami naprawczymi przy zastosowaniu różnych technik wzmocnienia i metod wzmacniania. Tak opracowane metody obliczania odkształceń mogą mieć zastosowanie do prognozowania zachowania się wzmacnianych belek żelbetowych. Między innymi w pracy [6] zaproponowano trójliniowy model matematyczny zależności moment - krzywizna dla przekrojów żelbetowych wzmacnianych przed obciążeniem, który posłużył do obliczania odkształceń belek żelbetowych w całym zakresie obciążeń [8].

Przedstawione ścieżki równowagi statycznej mogą mieć zastosowanie w opracowaniu algorytmów do wymiarowania wzmocnień belek żelbetowych w strefie zginania i analizy odkształceń tych belek. Zaprezentowane ścieżki równowagi statycznej uwzględniają wszystkie aspekty wykonywania wzmocnień belek żelbetowych $\mathrm{w}$ strefie zginania, do których zalicza się właściwości mechaniczne materiałów naprawczych, techniki wzmocnień i metody wzmacniania.

\section{Literatura}

[1] Biegus A., Nośność graniczna stalowych konstrukcji prętowych, Wydawnictwo Naukowe PWN, Warszawa, 1997.

[2] Czarnecki M., Emmons P.H., Naprawa i ochrona konstrukcji betonowych, Polski Cement, Kraków, 2002. 
[3] Externally bonded FRP reinforcement for RC structures, Technical Report, Fib Bulletin, No 14, Lausanne, 2001.

[4] Kamińska M.E., Kotynia R., Doświadczalne badania żelbetowych belek wzmocnionych taśmami CFRP, Zeszyt 9, Wydawnictwo Katedry Budownictwa Betonowego Politechniki Łódzkiej, Łódź, 2000.

[5] Korentz J., Efektywność technik wzmacniania belek żelbetowych, Renowacja budynków i obszarów zabudowanych, t.5, 2009, s. 301-308.

[6] Korentz J., Model zależność moment-krzywizna dla wzmocnionych żelbetowych przekrojów zginanych, Konstrukcje zespolone, 2011, s. 117-124.

[7] Korentz J., Metoda analizy żelbetowych elementów prętowych w stanie deformacji pozakrytycznych, Studia z zakresu Inżynierii 90, 2015, KILiW PAN.

[8] Korentz J., Metoda obliczania ugięcia belek żelbetowych wzmocnionych materiałem kompozytowym, Zeszyty Naukowe Politechniki Rzeszowskiej, Nr 3/2011/II, 2011, s. $143-150$.

[9] Kotynia R., Przyczepnościowe metody wzmacniania konstrukcji żelbetowych przy użyciu naprężonych kompozytów polimerowych, Przegląd Budowlany, 7-8, 2015, s. 49-56.

[10] Kotynia R., Przygocka M., Lasek K., Wpływ wstępnego wytężenia płyt żelbetowych na efekt wzmocnień naprężonymi kompozytami CFRP, Konstrukcje betonowe i metalowe, Wydawnictwo Uczelniane UT-P w Bydgoszczy, 2016, s. 47-54.

[11] Kotynia R., Kamińska M.E., Odkształcalność i sposób zniszczenia żelbetowych belek wzmocnionych na zginanie materiałami kompozytowymi CFRP, Zeszyt 13, Wydawnictwo Katedry Budownictwa Betonowego Politechniki Łódzkiej, Łódź, 2003.

[12] Masłowski E., Spiżewska D., Wzmacnianie konstrukcji budowlanych, Arkady, Warszawa, 2000.

[13] Runkiewicz L., Wzmacnianie konstrukcji żelbetowych, Instytut Techniki Budowlanej, Warszawa, 2011.

[14] Smith S.T., Teng J.G., FRP-strengthened RC beams. I: review of debonding strength models, Engineering Structures, No 24, 2002, s. 385-395.

[15] Urban T., Wzmacnianie konstrukcji żelbetowych metodami tradycyjnymi, Wydawnictwo Naukowe PWN, Warszawa, 2015.

[16] XTRACT v3.0.8, Cross-sectional X Structural Analysis of Components, Imbsen Software System, 2007, http://www.imbsen.com (maj 2017).

\section{STATIC EQUILIBRIUM PATHS FOR CFRP STRENGTHENED REINFORCED CONCRETE BEAMS}

\section{S u m m a r y}

The results of experimental tests and numerical analyses indicate that repair techniques and the mechanical characteristics of repair materials have a very strong influence on the behaviour of strengthened reinforced concrete beams. The mechanical characteristics of materials used for strengthening elements and the strengthening techniques determine not only the load bearing capacity of beams after strengthening, but also their deformations. Other important factors also 
affect the behaviour of such beams, which include the time when the strengthening is done, i.e. before or after loading the beam. It is also important whether the beams are compressed with repair materials while they are being strengthened, or whether the load is taken off the beams before strengthening, or whether intermediate supports are used while strengthening the beams. All the factors mentioned have an influence on the behaviour of strengthened reinforced concrete beams. While designing strengthening elements for reinforced concrete beams, it is necessary to be aware of the consequences of using available repair techniques, repair materials, as well as the technology and stages of the construction of strengthening elements. The paper presents the static equilibrium paths of strengthened reinforced concrete beams with special attention to the repair techniques possible to implement while strengthening the beams. These analyses can be useful for designing strengthening elements for reinforced concrete beams.

Keywords: loading, unloading, compression, bending moment, curvature, deflection

Przestano do redakcji: 30.05 .2017 r.

Przyjęto do druku: 01.09.2017 r. 